\title{
How Much Do Employers Learn from Referrals?*
}

\author{
Joshua C. Pinkston \\ University of Louisville
}

January 2011

\begin{abstract}
This paper tests the hypothesis that referrals from various sources provide employers with more information about job applicants than they would have without a referral. I use data that contain information on two workers in the same job, allowing me to cancel out differences in job and firm characteristics and control for the possibility that workers with referrals from different sources (or no referral at all) sort into jobs that put different weights on individual performance. The estimation results are consistent with referrals from current employees providing employers with more information than they would have otherwise. Additionally, it appears as though hiring through friends or relatives of the employer may involve some favoritism that results in employers either collecting less information than they would otherwise or ignoring information when setting wages. I also find weak evidence consistent with referrals from other firms or labor unions providing useful information, and no evidence that referrals from community organizations or other sources have any effect.
\end{abstract}

JEL Codes: J6, M51, J31, D83

Keywords: Referrals, recruiting methods, labor market information

*I owe special thanks to Tricia Gladden, Jeff Groen, Anne Polivka, and Kathryn Shaw for helpful comments. I would also like to thank seminar participants at the 2006 SoLE meetings; Florida State University; The University of North Carolina, Chapel Hill; Clemson University; The University of Texas, Arlington; and The University of Louisville. All mistakes are my own.

Address: Economics Department, College of Business, University of Louisville, Louisville, KY, 40292

Phone: (502) 852-2342. Email: Josh.Pinkston@ louisville.edu 
This paper tests the hypothesis that referrals from various sources provide employers with more information about job applicants than they would have without a referral. The focus is on two testable implications of this hypothesis. First, since more precise information at the time of hiring will make employers more confident in their initial estimates of a worker's productivity, the initial wages of workers who received an informative referral should be more correlated with the employers' evaluations of their productivity than will the wages of workers who are hired without a referral. Secondly, employer learning will have less of an effect on the wages of workers who received informative referrals than it will on the wages of workers hired without a referral because employers will have less to learn about referred workers' productivity.

The importance of referrals to both the recruitment efforts of firms and the job search of individuals is well known. Rees and Schultz (1970) found that referrals are the most commonly used informal recruitment channel, and are the preferred method of recruitment for some firms. Holzer (1987) and Castilla (2005) found that referrals from employees and other employers produce new hires with higher performance and lower turnover. Holzer (1988), and Blau and Robins (1990) present evidence suggesting that referrals from friends and family members are more effective at producing job offers and acceptances than are other search methods.

The idea that referrals provide employers with more precise information than other hiring channels do is not new. Rees and Schultz (1970) argue that referrals being informative could explain their findings. It also provides an intuitively 
appealing explanation for the other results noted above. All of these findings, however, have alternative explanations, leaving open the question of whether or not referrals really are as informative as we think they are.

Perhaps the simplest explanation for the previous literature's observations about referrals is that referrals allow firms to select from a pool of more capable applicants. ${ }^{1}$ Kugler (2003) and others have suggested that referred workers might also be preferred by some employers because the employee who referred them can exert peer pressure. ${ }^{2}$ Reynolds (1951) argues that the use of referrals produces "congeniality in the work force" and new hires who live close to the plant, both of which improve retention. ${ }^{3}$ Fernandez and Weinberg (1997) suggest that the effectiveness of referrals at producing job offers may stem from referred workers having inside information about that firm's hiring practices. Finally, Loury (2006) provides evidence that, in some cases, the lower turnover of referred workers might be due to referrals being used as a last resort by workers who have few alternatives.

The only previous work in the economics literature to test the hypothesis that referrals provide employers with more precise information than other recruiting methods is Simon and Warner (1992). Using the matching framework of Jovanovic (1979), they argue that if referrals reduce uncertainty about match productivity they will result in higher initial wages and lower average wage

\footnotetext{
1 For example, Saloner (1985) develops a model in which referrers only refer those who are most likely to be of higher ability. Montgomery (1991) suggests that employee referrals might alleviate adverse selection involved in hiring, benefiting both well-connected workers and firms that hire through referrals.

2 This is consistent with Castilla (2005) finding that increases in performance associated with referrals in a call center is contingent on the referrer staying with the firm.

3 Shinnar, et al (2004) suggest that even the act of referring a job applicant can improve a referring worker's attitude toward the firm.
} 
growth on the job, as well as lower quit rates. Their estimates from a sample of scientists and engineers support these predictions.

Unfortunately, the empirical results of Simon and Warner (1992) could also be explained by factors other than the informational content of referrals. As they acknowledge, the predictions of their model cannot be distinguished from effects due to favoritism. Their predictions would also follow if referred workers were initially more productive than others and non-referred workers underwent additional training on the job to catch up. ${ }^{4}$ Finally, their data limit the ability to control for referrals sorting workers into different types of jobs than other recruiting channels do, as is predicted by Kugler (2003) and suggested by the empirical results of Devaro (2005)..$^{5,6}$

Fernandez, Castilla and Moore (2000) (FCM) also consider the hypothesis that employers learn more from referrals than from other recruiting channels in their extensive examination of hiring in a customer service phone center. ${ }^{7}$ They argue that, if referrals from current employees are informative, the characteristics of the referrers will be correlated with the probability of the referred applicants receiving an interview or a job offer. Characteristics of the referrer, however, might also be correlated with characteristics of the applicants due to homophily in social networks, which implies that their tested prediction

\footnotetext{
4 See Mortensen (1988) for a discussion of how similar the empirical implications of matching and on-the-job training can be.

5 The sample Simon and Warner (1992) use may alleviate this problem; however, it is unlikely that all jobs that hire engineers or scientists put the same amount of weight on individual performance when setting wages and are uniform in unobserved qualities.

${ }^{6}$ Kugler (2003) develops a model of dual labor markets in which "good" jobs are sensitive to individual performance and require a referral. Devaro (2005) documents associations between skill requirements and other job characteristics and the firm's choice of recruiting method.

7 Castilla (2005) suggests that differences in productivity can be used to test this hypothesis; however, productivity differences could arise for many reasons, as noted above.
} 
could also be explained by referral applicants being drawn from a better pool of workers. ${ }^{8}$ Furthermore, even if HR personnel in this establishment do form expectations about an applicant based in part on the characteristics of the referring worker, this test says nothing about how accurate those expectations are relative to expectations formed when another worker responds to a newspaper add or walks in off the street. ${ }^{9}$

The tests in the current paper are based on previous work on statistical discrimination and the tested predictions hold in any environment in which wages are based on expected productivity, including the matching framework used by Simon and Warner (1992). An important contribution of this paper is that the tested predictions can be distinguished from effects of average productivity differing by referral type, and from effects of favoritism. ${ }^{10}$ Furthermore, the data used in this paper includes information on two workers in the same job, which allows differences in job and firm characteristics to be removed.

The estimation results are consistent with referrals from current employees providing employers with more information than they would have otherwise. Additionally, I find evidence that suggests hiring through friends or relatives of

\footnotetext{
8 The fact that HR personnel in the firm FCM study claim to never have time to talk to workers who refer applicants would make it even more likely that a positive result from this test (which they don't find) is due to homophily in social networks.

Yakubovich and Lup (2006) look at a different firm, and do find evidence consistent with the proposed test in FCM; however, they seem to attribute it to productive workers simply referring more productive applicants. Consistent with this interpretation, they only find an effect of the referrer's characteristics on objective steps in the evaluation process (such as test scores), as opposed to subjective steps where the conditional expectation of the applicant's productivity might matter.

9 Walking into an establishment in response to a "help wanted" sign could send a very clear signal, depending on the employer's past experience. Furthermore, not being referred could also be informative, just as not having a certain level of education can be informative.

10 Simon and Warner (1992) argued that distinguishing differences in information from favoritism was an important task for future research.
} 
the employer involves favoritism that results in employers' either collecting less information than they would otherwise or ignoring information when setting wages. I find weak evidence of referrals from other firms and labor unions being informative, and no evidence that referrals from schools, community organizations or other sources provide any useful information.

The next section explains how differences in the reliability of initial information can affect wages. Section 2 then describes the data used in this paper. Section 3 discusses estimation, as well as issues such as favoritism and unobserved job characteristics. Section 4 presents estimation results, and Section 5 concludes.

\section{Wages, Performance and Initial Information}

The tests conducted in this paper are based on the framework developed in Pinkston (2003) to test the hypothesis that employers are better able to evaluate the ability of men at the time of hiring than the ability of women. Whether one is considering differences based on gender or referrals the implications are the same:

1. The more accurate the employer's initial signal of worker productivity is the more that worker's wage will be correlated with the employer's assessment of the worker's ability, and

2. The more accurate initial information is the less employer learning will affect wages as tenure increases. 
Suppose a firm observes a signal of productivity for each worker $i$ who received a referral of type $j$ at the time of hiring:

$$
s_{i j}=\mu_{0 i}+\varepsilon_{i j}
$$

where $\mu_{0 i}$ is worker $i$ 's productivity, $\varepsilon_{i j} \sim N\left(0, \sigma_{\varepsilon j}^{2}\right)$ and $\sigma_{\varepsilon j}^{2}$ varies by referral type $j$. This signal can include information gathered from initial interviews and tests, as well as whatever the referrer said about the worker. The important assumption at this point is that any information contained in a referral affects the variance of the initial signal around the worker's true productivity. As that information becomes more (or less) reliable, $\sigma_{\varepsilon j}^{2}$ decreases (increases).

Assume the employer also observes a vector of worker characteristics $X_{i}$ and initial productivity is a known linear function of $X_{i}$ and an error term:

$$
\mu_{0 i}=X_{i} \beta+v_{i}, v_{i} \sim N\left(0, \sigma_{v}^{2}\right)
$$

where $\beta$ is common knowledge and $\sigma_{\nu}^{2}$ is the same for all groups. The initial signal can then be used to predict the part of a worker's productivity that is not already explained by education and other easily-observed characteristics. Letting $\widetilde{s}_{i j}$ denote the part of $s_{i j}$ that is not correlated with $X_{i}$, the conditional expectation of productivity given $X_{i}$ and $s_{i j}$ is

$$
E\left(\mu_{0 i} \mid X_{i}, s_{i j}\right)=X_{i} \beta+\alpha_{j} \widetilde{s}_{i j}
$$

where $\alpha_{j}=\frac{\sigma_{v}^{2}}{\sigma_{\varepsilon j}^{2}+\sigma_{v}^{2}}$. It is now easy to see that the more precise the signal from a referral of type $j$, the smaller $\sigma_{\varepsilon j}^{2}$ is and the larger $\alpha_{j}$ is. 
The assumption implicit in equation (1) that initial productivity does not vary by group is made for the sake of simplicity. Aigner and Cain (1977) discuss analogous distinctions between effects of differences in the precision of information and effects of differences in average ability across groups in the context of statistical discrimination based on race. Similarly, the tested implications in this paper are robust to groups differing in productivity, as long as the variance of productivity that is not explained by observable characteristics, $\sigma_{v}^{2}$, is the same for all groups. ${ }^{11}$ Therefore, the empirical results of this paper cannot be explained by referred workers being more capable, or performing better due to peer pressure.

Of course, we do not observe the initial signal $s_{i j}$ in the data. ${ }^{12}$ What we do observe is an employer-provided evaluation of the worker's productivity at some tenure $t$. Assume for now that the evaluation of productivity at $t$ is

$$
P_{t j}=S_{t j}+Z_{t} \gamma
$$

where $S_{t j}$ is an unbiased estimate of initial ability based on the initial signal $s_{i j}$ and performance on the job, and $Z_{t} \gamma$ is the known effect of tenure and training on productivity. ${ }^{13}$ As Pinkston (2003) discusses in greater detail, the variance of $S_{t j}$ is higher for higher values of the initial signal's variance, $\sigma_{\varepsilon j}^{2}$; but it also

\footnotetext{
11 This is a generalization of the model in Aigner and Cain (1977), which assumed that the variance of $\mu_{0 i}$ did not differ between groups. If $\sigma_{\nu}^{2}$ is larger for one group, contrary to the weaker assumption made above, then more weight will be placed on both initial signals and later performance. (Intuitively, there would be more left for these signals to explain.) While a higher value of $\sigma_{\nu}^{2}$ could mimic the initial effect of an informative referral, it would produce the opposite effect on employer learning. Therefore, a deviation from this assumption could not be confused with an informative referral, as long as we consider both of the tests discussed in this paper.

12 Note that, even though we observe the type of referral that worker's receive, we cannot observe the information the referrer passed on to the employer.

$13 S_{t j}$ can be modeled using a standard Bayesian updating argument, making it a weighted average of the employer's initial signal and a sequence of per-period performance observations.
} 
decreases in tenure faster for higher values of $\sigma_{\varepsilon j}^{2}$. In other words, the precision of the productivity measure is increasing in tenure for all workers, but increases more quickly for groups with less precise initial signals.

Assuming wages at tenure $t$ are equal to expected productivity conditional on observed characteristics and $P_{t}$, we can write

$$
w_{t j}=E\left(\mu_{t} \mid X, P_{t}\right)=X \beta_{t j}+\alpha_{P j} P_{t j} .
$$

The coefficient $\alpha_{P j}$ increases in tenure as employers learn and $P_{t j}$ becomes more precise; however, it increases more slowly the more precise initial information is. In other words, the more information the employer had initially, the less important later learning is. Furthermore, at $t=0, \alpha_{P j}$ is an unbiased estimate of $\alpha_{j}$ from equation (2). ${ }^{14}$ The more precise the initial signal is the larger this initial effect will be.

\section{The EOPP Data}

This paper uses data from the 1982 survey of the Employment Opportunity

Pilot Project (EOPP), which contains responses from 3,420 establishments in 28 survey sites. ${ }^{15}$ The 1982 survey followed the original 1980 EOPP survey, which was designed to evaluate the effects of a job search and training pro-

\footnotetext{
14 This assumes that employers learn about workers with different types of referrals at the same rate. If they learn more slowly about one group, estimates of the initial effect might suggest that group's initial signals are less reliable than they really are; however, the slower rate of learning would counteract the greater importance of employer learning caused by less reliable initial signals. Therefore, if both initial effects and results based on employer learning suggest that employers receive less reliable signals for one group than for another, we can be confident that our results are not due to this bias.

15 This survey was collected by Gallup for the U.S. Department of Labor. The original 1980 survey was collected by collected by Westat. The data are availale through the CISER Data Archive at Cornell University.
} 
gram. ${ }^{16}$ The 1980 survey oversampled establishments with a high proportion of low-wage employees, and the 1982 survey attempted to follow up with the same establishments. Establishments in both surveys were asked for information about the last worker hired, but only the 1982 survey contains the information on recruiting methods this paper requires.

An important feature of the 1982 EOPP data is that they contain a subsample of roughly 650 establishments that report data on a second worker hired for the same job as the last worker hired. ${ }^{17}$ Differencing two workers in the same job and establishment reduces bias caused by correlations between referrals and job characteristics. (The next subsection discusses this in greater detail.) For the sake of consistency, I restrict all estimates to this subsample even when those estimates do not use differences between two workers; however, non-differenced results in the full sample (not shown) are qualitatively similar to those from the restricted sample. ${ }^{18}$

The productivity evaluations in the data are the employer's ranking of the worker's productivity in that job on a scale of zero to $100 .{ }^{19}$ A rating of 100

\footnotetext{
16 The 28 survey sites include 9 "pilot sites" that had the program and 19 control sites. Most of the sites where metropolitan areas, but nine were collections of rural counties.

17 The survey explicitly states that this second employee should be someone who was "hired for the same or similar position" as the last worker hired, and job characteristics like occupation are recorded once for the worker pair. The median of the absolute value of starting wage differences is $\$ 0.15$ in nominal wages and $\$ 0.23$ in real 1982 dollars. 90 percent differ by $\$ 1.15$ or less in nominal terms and $\$ 1.59$ or less in 1982 dollars.

18 The primary difference between the subsample with data on two workers and the rest of the sample is that establishments that report data on two recently hired workers tend to hire more frequently. When a dummy variable for the worker being the second worker is included in wage regressions, the coefficient is small and statisticaly insignificant.

19 The interviewer asks to speak with the person responsible for hiring in each establishment. I assume, as does the survey, that this person also has sufficient information to judge the workers' productivity on the job. Bishop (1987) notes that, because most of the interviewed establishments are relatively small, the person responsible for hiring was usually the owner or manager of the establishment. Nonetheless, there is variance across recruiting channels in establishment size. Since it is possible that respondents in large establishments observe workers less closely, Section 4.2 will discuss robustness of the main results to restrictions on
} 
indicates the highest possible productivity of a worker in that position. This is explained to the respondent, and they are then asked to rate each worker (and the "typical worker") at three different points: the first two weeks on the job, from the third to the twelfth week, and at either the date of the interview or the last week the worker was employed by the firm. ${ }^{20} \mathrm{I}$ use the last of these evaluations and refer to it as "current productivity" in what follows. ${ }^{21}$

The data also contain questions about how the worker was hired; i.e., using a newspaper ad, a referral from a current employee, etc. These questions identify several sources of referrals that are mutually exclusive in the data. Since the source likely affects how informative a referral is, I divide my sample into workers who were referred by an employee of the firm, workers referred by a friend or relative of the employer, workers referred by another employer or a labor union, all other referrals and no referral at all. ${ }^{22}$

sample size.

${ }^{20}$ If the employee is still with the establishment, which describes $67 \%$ of observations, the wage and performance evaluation are taken at the time of interview. If the employee no longer works at the firm, the wage and performance evaluation are the most recent available.

When a dummy variable for the worker still be employed by the firm is added to regressions, its coefficient is not statistically significant and other results do not change. Limiting attention to cases in which neither worker left produces qualitatively similar results, but standard errors are much higher due to the smaller sample size.

21 Previous versions of the paper also used the measure of productivity in the first two weeks on the job as a proxy for the initial signal in a regression based on equation (2). Since it is not clear how this measure relates to the initial signal (whether it's influenced by more recent performance, etc.), it is difficult to know what bias its use as a proxy introduces. Furthermore, this measure becomes less correlated with initial wages as the time since the worker started increases, suggesting recall bias. Since referral types differ in the average time since the worker's start date, this recall bias could influence comparisons of referral types. Regressions that relied on this early measure of productivity did not provide evidence consitent with referrals being informative.

22 I group referrals from friends and family of the employer together, and group referrals from other employers with those from labor unions due to the small sample size. "Other" referrals come from schools, employment agencies, community organizations, etc. Preliminary estimation that separated each of these groups into more specific referral types suggested that the component types behave similarly. Intuitively, firms and unions are both professional connections, while "other" referrals come from organizations that might be assisting low-skilled workers. 
Limiting attention to establishments that report at least some information on two workers leaves 659 establishments (and worker pairs). I then drop 46 worker pairs in which the workers' pay is based on commission, tips or a piecerate scale; 13 pairs in which one worker's start date was more than four years before the interview date; 37 pairs in which tenure is not reported for one of the workers and cannot be calculated because start date is not reported; and two pairs in which one worker was younger than $16 .^{23,}{ }^{24}$ Finally, two pairs are excluded because they appear unlikely to have been hired for the same job. ${ }^{25}$ The resulting sample has 447 worker pairs and 894 individual workers.

Table 1 presents summary statistics for the sample. The average starting wage is $\$ 5.15$ (in inflation-adjusted 1982 dollars) and the average current wage is $\$ 5.48$. The average worker has 10.9 months of tenure with the employer, and almost 43 months of prior experience that the employer believes "had some application to the position". The average productivity of a worker in her first two weeks, on a scale of 0 to 100 , is 52.47 , and the average current productivity is $76.27 .^{26}$ About $45 \%$ of the sample of 894 workers had no referral, $26 \%$ were

\footnotetext{
23 Workers paid by piece-rate, commission or tips are excluded because such pay reflects the worker's actual performance, not the employer's expectation of that worker's productivity. Because the tests in this paper are based on employers' expectations, including these observations biases results and creates the impression that employers know more about worker productivity than they really do. The correlation of wages and performance is over three times as large in these jobs as in the estimation sample. (If this correlation weren't higher, we would have reason to worry about the performance measure.)

I found no evidence that these jobs are associated with any referral types. I also estimated a regression on a sample that did include these jobs, but used interaction terms to allow the relationship between wages and performance to be different for jobs in which pay is based directly on performance. The results were similar to those presented in Section 4 for jobs that don't involve performance pay.

24 Workers who started more than four years before the interview date are excluded because their employers are outliers in terms of how infrequently they hire. Preliminary estimation obtained qualitatively similar results without this restriction, or that on age.

25 Their starting wages differ by over $\$ 10$ per hour, their ages differ by 23 or more years, and their relevant experience differs by almost 20 years.

26 The distribution of current productivity is skewed to the right. The median is 80,75
} 
referred by an employee of the firm, $5.4 \%$ by a friend or family member of the employer, $5.5 \%$ by another employer or a labor union, and $18 \%$ were referred by some other source.

Table 2 presents summary statistics separately for each referral type, and suggests that different types of referrals are associated with different worker and job characteristics. The wages and productivity of workers with referrals from other firms or unions are significantly higher than the wages and productivity of workers with no referral, while the early productivity of workers with a referral from community groups, schools, etc. is slightly lower. The average worker who was referred by a friend or relative of the employer works in an establishment of 31 workers, while the average worker who was hired without a referral is in an establishment with 200 workers. Workers referred by an employee of the firm have higher tenure than workers hired without a referral. ${ }^{27}$ They are also more likely to be in professional, managerial and technical occupations than are workers with no referral, and are less likely to be in bench work occupations. ${ }^{28}$

Finally, it should be acknowledged that this survey is over two decades old, and we should be cautious about generalizing results to more recent labor markets. Nonetheless, the data provide a unique opportunity to study referrals, and more recent evidence suggests referrals are still an important part of hiring and job search. Holzer (1996) finds similar percentages of workers being hired

percent have an evaluation of 70 or higher, and 90 percent have an evaluation or 50 or higher. As noted in Frazis and Loewenstein (2007), reported values also tend to be clustered at multiples of 5 . Section 3.3 will discuss the robustness of tests to relaxing assumptions about the productivity measure.

27 Because the survey is based on the last worker hired, tenure is at least as much of an establishment characteristic as an individual match characteristic.

${ }^{28}$ Bench work occupations involve the fabrication, assembly or repair of various products. Examples include wood working, watch repair, and fabricating medical prosthetics. 
through referrals in data collected between 1992 and $1994 .{ }^{29}$ Using more recent data, Marmaros and Sacerdote (2002) and Mayer (2010) find that social networks play an important role in the labor market outcomes of recent college graduates. ${ }^{30}$ Finally, a simple comparison of data on job search methods used by respondents in the 2007 wave of the NLSY97 to methods used by respondents in the 1986 wave of the NLSY79 suggests that the use of friends and family has, if anything, increased over the past two decades. ${ }^{31}$

\section{$3 \quad$ Estimation and Alternative Explanations}

Wage regressions based on equation (3) approximate $\alpha_{P j}$ using a linear interaction of performance with tenure:

$$
w_{t j}=X \beta_{t j}+\alpha_{0} P_{t j}+\alpha_{t} t P_{t j}+\sum_{j}\left(\begin{array}{c}
\gamma_{j} D_{j}+\gamma_{t j} t D_{j}+ \\
\alpha_{0 j} D_{j} P_{t j}+\alpha_{t j} t D_{j} P_{t j}
\end{array}\right),
$$

where $D_{j}$ are dummy variables for referral group (the omitted group is those with no referral); and $X$ controls for observed characteristics, including tenure and a constant. The coefficients on productivity interacted with the group dummies, $\alpha_{0 j}$, capture the difference in the initial signal's effect on starting

\footnotetext{
${ }^{29} 25-26 \%$ were referred by current employees; $13-15 \%$ by the sum of unions, the employers' acquaintances, etc.; and $13-18 \%$ by employment services, community groups and schools. The data he used came from the Multi-City Study of Urban Inequality, which would not allow a comparision of two workers in the same job. The ranges in estimates depend on the subsample used.

30 Marmaros and Sacerdote (2002) examine the use of social networks among the Dartmouth College class of 2001 to obtain their first jobs. Mayer (2010) finds evidence that social connections through Facebook.com positively affect the job prospects of students who graduated from Texas A\&M between 2005 and 2008.

${ }^{31}$ Each survey asks a series of questions about job search methods used during the respondents' most recent unemployment spell. Limiting each sample to workers who were 22-28 years old, I found that roughly $41 \%$ contacted friends and family in 1986 , while almost $54 \%$ contacted friends and family in 2007. I leave a more careful analysis of how job search methods have changed over time to future research.
} 
wages for group $j$ relative to those without referrals, while $\alpha_{t j}$ captures the difference in the effect of employer learning for that group. ${ }^{32}$ If the signals employers receive when hiring workers through referral type $j$ are informative, $\alpha_{0 j}$ will be positive and $\alpha_{t j}$ will be negative. This reflects the greater initial weight put on productivity and lower effect of learning for that referral type.

The dummy variables for referral type and the interactions of those referral variables with tenure will capture many possible effects of referrals. For example, initial beliefs (correct or not) about average productivity differences across referral types would affect $\gamma_{j}$, the coefficients on referral dummy variables. Effects of referrals on productivity after the worker is hired would be captured by referral type interacted with tenure. ${ }^{33}$ In any case, the specific implications this paper tests do not involve wage premiums, group-specific differences in productivity or other effects of referrals reflected in $\gamma_{j}$ and $\gamma_{t j}$. They involve the correlation of wages and productivity reflected in $\alpha_{0 j}$ and $\alpha_{t j}$.

All regressions use wage levels, not logs. ${ }^{34}$ The individual characteristics contained in $X$ are gender, a quartic polynomial in age, experience the em-

\footnotetext{
${ }^{32}$ I experimented with interactions of nonlinear functions of tenure that could better approximate $\alpha_{P j}$. Although results using these specifications were qualitatively similar to the results presented in section 4 , these specifications appeared to ask too much of the small sample, resulting in larger standard errors.

Since $\alpha_{0 j}$ are essentially intercepts, some might worry they would be particulary sensitive to the specification of $\alpha_{P j}$; however, this does not appear to be a problem. The estimated values of $\alpha_{0 j}$ presented below are similar in quadratic specifications. Furthermore, re-estimating regressions that use the linear interactions under various restrictions on tenure (tenure $\leq 30$, 20,15 or 10 months) suggests that these estimates are not driven by extreme values of tenure.

${ }^{33}$ It's possible that the effects of tenure and training on productivity are not uniform across referral types, as assumed in Section 1; however, controlling for both tenure and its interaction in the wage regressions should remove effects of tenure on performance whether they differ by referral type or not. Although training is not included in most specifications due to its likely endogeneity, a specification that does include it is presented in Section 4.2 as a robustness check. Furthermore, a regression of performance on tenure, referral type and their interactions, which is presented in Section 4.3, should reflect post-hire effects of referrals on performance.

${ }^{34}$ This is more consistent with the model, which is in wage levels. Pinkston (2003) does the same thing. The results, however, are not qualitatively affected by this decision.
} 
ployer considers relevant, dummy variables for education level, and missing value dummy variables for age, experience, and education. In specifications that do not use differences between workers in the same job, I control for differences in job characteristics by including establishment size, the percent of employees that are unionized, a missing value dummy for that percent, and dummy variables for occupation, industry and survey site.

\subsection{Favoritism and Social Networks}

The effects of favoritism are easily separated from evidence of informative referrals in results based on equation (4). The coefficients on the dummy variables for referral type, $\gamma_{j}$, will capture any initial premium paid to workers who have certain connections. ${ }^{35}$ If such a premium then decreases with tenure, which would be consistent with Simon and Warner (1992), the coefficient on that referral type interacted with tenure, $\gamma_{t j}$, will reflect that decrease.

Favoritism could also result in employers bypassing normal screening procedures when hiring a worker, or otherwise result in hiring and wage decisions being based on something other than information about productivity. ${ }^{36}$ In those

\footnotetext{
35 This premium could come about through incorrect beliefs, as mentioned above. For example, employers might believe that anyone they hire through their family is more capable than they really are, and they might even give them higher performance evaluations to justify their beliefs. (I thank an anonymous referee for making this point.) The dummy variable for such a referral should remove both the effects of incorrect beleifs about group averages and the effects of members of that group having inflated performance evaluations. This will be examined empirically in Section 4.

36 This could also arise from incorrect beliefs if employers only have incorrect beliefs about the specific members of a group that they encounter but otherwise have correct beliefs about the average productivity for that group. E.g., employers might believe that workers hired through family connections have lower ability on average, but still believe that one of their family members is more capable than she really is. If such beliefs are treated as separate information from the correct beliefs about group averages, they would reduce the weight placed on unbiased signals the employer received, mimicking the employer having less information.
} 
cases, favoritism would have the opposite effect on the correlation between wages and productivity evaluations as an informative referral. A referral type that involved favoritism might initially appear to provide less information about the worker than no referral, and employer learning would have a greater effect on later wages. ${ }^{37}$ In other words, $\alpha_{0 j}$ in equation (4) would be negative, and $\alpha_{t j}$ would be positive.

It's also possible that workers who are capable of getting referrals to employers in the survey have better social networks than workers hired without referrals, and they might receive more (or better) outside offers as a result. In models of asymmetric employer learning, firms often pay workers less than their expected productivity because competition is limited by other firms knowing less about the worker than the current employer does. ${ }^{38}$ Pinkston (2009) shows that, if outside employers are capable of collecting private signals (through interviews, for example), competition can cause wages to converge to the employer's conditional expectation despite the current employer having more precise information. Therefore, wages might be more correlated with productivity for some referral types simply because those referral types are associated with better social networks and greater competition for the workers' labor.

In contrast to the predictions I test, such differences in social networks would imply that the correlation of wages and productivity would increase faster with

\footnotetext{
37 This assumes that the effects of favoritism dissipate over time, which would be required if it were to explain the results of Simon and Warner (1992). A declining effect of favoritism could be explained by the favored worker increasingly being compared to coworkers that the employer is more familiar with (and perhaps more fond of).

38 Gibbons and Waldman (1999) provide a survey of this literature. For two examples, see Waldman (1984) and Scoones and Bernhardt (1998).
} 
tenure for referral types that are associated with better social networks because increased competition from outside firms would reduce an employer's ability to exploit an informational advantage. Furthermore, this increase in competition would imply a higher quit rate for those referral types, which does not fit the data. $^{39}$

Finally, note that applicants, as well as firms, can learn from referrals. ${ }^{40}$ If applicants use their social networks simply to find jobs that pay better, the referral-specific intercepts would be affected, but the tests this paper focuses on would not be. On the other hand, applicants using their social networks to find jobs that base pay more on performance than other jobs do could affect the outcomes of our tests. Essentially, this might be an avenue through which the worker sorting Kugler (2003) discusses might unfold, and it provides another reason to compare workers who are in the same job, as is discussed in the next subsection.

\subsection{Unobserved Job Characteristics}

As mentioned above, there is reason to worry that referral type might be associated with unobserved job characteristics. To model this in a simple manner,

\footnotetext{
39 Holzer (1987) finds that workers referred by an employee are more likely to still be employed by the firm at the time of interview. In my own regressions (not shown), I do not find a statistically significant relationship, but the results are qualitatively similar to Holzer's.

${ }^{40}$ In the economics literature this is often discussed as a means of learning about potential job openings. Examples include Montgomery (1991) and Calvó-Armengol and Jackson (2004).

In the sociology literature (e.g., Fernandez and Weinberg (1997) and FCM) there appears to be more interest in applicants learning about the organization itself.
} 
we can add an unobserved firm- or job-specific term to equation (4):

$$
w_{t j}=X \beta_{t j}+\alpha_{0} P_{t j}+\alpha_{t} t P_{t j}+\sum_{j}\left(\begin{array}{c}
\gamma_{j} D_{j}+\gamma_{t j} t D_{j}+ \\
\alpha_{0 j} D_{j} P_{t j}+\alpha_{t j} t D_{j} P_{t j}
\end{array}\right)+e_{f} .
$$

The possibility that $e_{f}$ is correlated with referral types suggests that any of the coefficients on referral dummy variables or their interactions could suffer from omitted variable bias. Productivity evaluations might also be correlated with $e_{f}$ if they are relative to the expectations of the specific job, introducing further bias.

Having data on two workers in the same job allows us to cancel out firm- or job-specific variables by considering differences between the two workers. Given two workers, $i=1,2$, the difference in current wages is

$$
\begin{aligned}
\Delta w_{t}= & \Delta X \beta_{t j}+\alpha_{0} \Delta P_{t}+\alpha_{t}\left(t_{1} P_{t 1}-t_{2} P_{t 2}\right) \\
& +\sum_{j}\left[\begin{array}{c}
\gamma_{j} \Delta D_{j}+\gamma_{t j}\left(t_{1} D_{1 j}-t_{2} D_{2 j}\right) \\
+\alpha_{0 j}\left(D_{1 j} P_{t 1}-D_{2 j} P_{t 2}\right) \\
+\alpha_{t j}\left(t_{1} D_{1 j} P_{t 1}-t_{2} D_{2 j} P_{t 2}\right)
\end{array}\right],
\end{aligned}
$$

where $D_{i j}$ are the dummy variables for worker $i$ having referral type $j$, and $P_{t i}$ are the evaluations of worker $i$. Any firm- or job-specific characteristics in $X$ or the error term cancel out, eliminating potential bias due to unobserved job characteristics.

A more difficult problem comes from the possibility that firms do not simply pay workers wages equal to expected productivity, and that there is heterogeneity across firms in the degree to which wages are correlated with productivity. If some referral types are associated with jobs that put more weight on individual 
productivity when setting wages, as suggested by Kugler (2003), both the initial effect of productivity on wages and the later effects of employer learning will be larger for those groups. This bias would not replicate the effect of employers' having more precise information, but it might obscure the true differences between groups. Fortunately, problems due to referrals being associated with jobs that put more or less weight on performance are also reduced by differencing, as the identification comes from jobs where the two workers have different referral types. ${ }^{41}$ In Section 4, I consider the degree to which the main results appear consistent with an association between referral type and the correlation of wages and productivity, along with other evidence that might suggest such an association.

\subsection{Assumptions about the Productivity Evaluation}

In Section 1, the productivity evaluation, $P_{t j}$, was assumed to be the sum of an unbiased estimate of initial ability and on-the-job human capital accumulation. As discussed in Section 2, the actual variable in the EOPP data is a subjective ranking of workers on a scale of zero to 100. Bishop (1987) points out that this measure cannot be treated as an absolute measure of productivity, but argues that it is an accurate measure of relative productivity when comparing two workers in the same job. ${ }^{42}$ Furthermore, this relative measure might be based on observed performance in period $t$, instead of being based on a weighted

\footnotetext{
41 Roughly $60 \%$ of workers who were hired through a referral of some type are paired with a worker who did not receive the same type of referral.

42 Bishop (1987) found that estimates of relative productivity differences within a job from the EOPP data are similar to estimates obtained in studies that used actual measures of output.
} 
average of every signal the firm has received since its first contact with the worker.

Neither of these deviations from the assumptions of Section 1 would qualitatively affect the predictions tested in this paper, but they might cause effects of productivity differences to be understated, making it more difficult to find evidence of informative referrals. ${ }^{43}$ Essentially, they both suggest that we observe something that is correlated with actual performance at $t, \mu_{t}$, instead of the unbiased result of employer learning plus accumulated human capital. The use of such a measure would be analogous to the use of test scores by Altonji and Pierret (2001) to investigate employer learning and statistical discrimination. ${ }^{44}$ We would still expect wages to be more correlated with such a measure when the employer had better initial information. Furthermore, wages would become more correlated with such a measure as the employer learned more about the worker, but employer learning would affect wages less when the employer knows more about the worker initially.

I consider two robustness checks to empirically support the argument that the use of a relative ranking instead of a measure of absolute productivity is not driving the results of this paper. The first is motivated by the observation that, if the observed productivity evaluation is based on a multiplicative rescaling of actual productivity, using differences in the natural log of the observed measure would allow that rescaling to difference out. Results from these estimates (not

\footnotetext{
43 Pinkston (2003) discusses this issue. Bishop (1987) argues that restricting the evaluation of productivity to a scale with an upper and lower bound also causes results to understate true effects.

44 The advantages of productivity evaluations over test scores include their incorporation of task-specific human capital and human capital accumulated on the job.
} 
shown) are qualitatively similar to those from the preferred specification, but some statistical significance is lost. ${ }^{45}$

The second robustness test, which is discussed further in Section 4.2, considers sensitivity of the results to adding job-specific variables that would be correlated with the typical level of absolute productivity expected in the job. This test is motivated by the observation that job-specific scaling of the productivity evaluations might not be differenced out in specification like that in equation (4). If the main results are affected by such job-specific terms being left in the error term of the differenced regressions, then adding variables to the regression that are correlated with the typical levels of productivity in the job should affect the results.

\section{Results}

The main results of the paper are presented in the following Subsection. If a type of referral is informative, we expect to see:

1. a positive coefficient on that referral type interacted with the productivity measure, and

2. a negative coefficient on the interaction of the referral type, productivity and tenure.

\footnotetext{
45 Recall that the producitivity evaluation is skewed to the right. Taking logs makes it more skewed and reduces the variation needed to identify effects of productivity differences. Coefficients from this specification are not directly comparable to those from the main specification, but the elasticities from the log specification are similar (if slightly smaller) to those implied by the main results at mean values of wage and productivity.
} 
On the other hand, we would expect the opposite results for referrals that involved favoritism; i.e., the results would appear to suggest such referrals were less informative than no referral at all. Section 4.2 presents empirical tests of the robustness of the main results. Section 4.3 presents supplementary results on effects of referrals on performance.

\subsection{Main Results}

The estimated coefficients presented in Table 3a suggest that referrals from employees and from other firms or unions provide employers with useful information. Significantly more weight is put on productivity initially for each of these referral types. The interaction of a referral from an employee with productivity has a coefficient of $0.0196(0.0101)$ in column II, which presents the differenced specification, and the coefficient on a referral from another firm or labor union is $0.0266(0.0155) .{ }^{46}$ Furthermore, the coefficients on Productivity $\times$ Tenure interacted with having a referral from an employee is $-0.0015(0.0007)$ and that on the interaction with a referral from another firm or labor union is $-0.0016(0.0022)$. While only the coefficient on the interaction with tenure and a referral from an employee is statistically significant, both of these effects are of the expected sign.

\footnotetext{
46 What might seem like small effects of productivity are not surprising. Previous work by Bishop (1987) and Frazis and Loewenstein (2007) documented that wages in this data are compressed relative to productivity. Uncertainty about workers' true abilities, which exists even with informative referrals, would reduce the correlation of individual productivity and wages. Furthermore, the problems discussed in Section 3.3 imply that these coefficients are smaller in magnitude than they would be if a measure of absolute (not relative) performance were used. Finally, over half the jobs in the data are in clerical, sales or service occupations where the correlation between wages and productivity is the weakest. ( 0.05 versus 0.196 for all other occupations.)
} 
Table 3a also presents evidence that is consistent with referrals from the employers' friends and relatives involving favoritism that allows these workers to bypass the firm's usual screening or wage-setting practices. The coefficient on productivity interacted with such a referral is $-0.0278(0.0120)$ and that on productivity interacted with both tenure and a referral from the employer's friends or family is $0.0021(0.0009)$. The coefficients are both statistically significant and have the opposite signs of what we would expect if this type of referral were informative.

Because the coefficients in Table 3a may be difficult to interpret, Table 3b presents differences in the effects of productivity on wages between each referral group and workers hired without a referral at various levels of tenure. At the time of hiring, a one-standard-deviation increase in productivity raises the wage of a worker referred by an employee by $\$ 0.39$ more per hour than it would increase the wage of a worker hired without a referral. This difference is almost $\$ 0.53$ if the worker was referred by another firm or a labor union. On the other hand, this increase in productivity would raise the hourly wage of a worker referred by a friend or relative of the employer by almost $\$ 0.56$ less than it would increase the wage of a worker hired with no referral at all.

These differences decrease over time as employers learn more about workers. Nonetheless, it takes roughly a year of tenure for an employer to learn as much about a worker hired without a referral as they knew about a worker who was referred by an employee at the time of hiring, and almost 17 months to learn as much as they knew about a worker referred by another firm or a union. It takes 
nearly 13 months for the apparent informational disadvantage of being referred by a friend or relative of the employer to dissipate. ${ }^{47}$

As was mentioned above, results that appear to suggest referrals from the employer's friends and family members are less informative than no referral at all are consistent with favoritism. These workers might be hired without being subjected to the firm's usual screening methods, or their initial wages might be set without regard to their expected productivity. Providing further evidence of favoritism, the results in Table $3 \mathrm{c}$ show that workers referred by friends or family of the employer are initially paid $\$ 0.52$ more per hour than workers hired without a referral, but this difference dissipates in roughly one year. ${ }^{48}$ This is the same pattern of wages found by Simon and Warner (1992). In contrast, the wage effects of a referral from an employee of the firm are relatively small, negative and statistically insignificant. The positive effect of referrals from other firms or labor unions appears to be constant over time, which might reflect a union wage premium. ${ }^{49}$

Looking back at Table $3 \mathrm{a}$, the importance of differencing two workers in the same job is made clear by comparing columns I and II. The coefficient on referrals from friends and family of the employer interacted with productivity

\footnotetext{
47 All of this analysis uses linear interactions with tenure; however, interactions with a quadratic in tenure yield qualitatively similar results. Unfortunately, standard errors in the quadratic and other nonlinear specifications are too large to see statistically significant effects, probably due to the small sample size.

48 These differences in effects of referrals on wages are calculated at average productivity.

49 As is discussed in Mouw (2003), care should be exercised when interpreting coefficients that suggest a wage premium. The referrals are likely correlated with unobserved characteristics. Therefore, it is not clear how much any "premium" reflects the return to a certain type of referral versus higher productivity among these workers. Given the evidence discussed elsewhere in this paper, it seems likely that very little of the initial premium paid to referrals from the employer's friends and family is due to higher productivity, while the higher wages paid to referrals from other firms and unions are more likely due to higher productivity.
} 
decreases significantly between columns. Both of the coefficients on interactions of a referral from another firm or labor union decrease in magnitude, and the change in the interaction with productivity and tenure is statistically significant. These differences are consistent with these referral types being associated with unobserved job characteristics, or with jobs that put more weight on individual productivity than other jobs do.

To investigate this possibility further, I estimated a regression similar to that in column I of Table 3a, but replaced the worker's own referral type and its interactions with the referral type of the other worker in the same job and its interactions. The information an employer has about a worker's productivity should not be affected by the referral of another worker, but any effect of a referral being associated with a certain type of job should be picked up. The results (not shown) suggest that the other worker being referred by another firm of labor union is associated with jobs that put more weight on productivity, further highlighting the importance of focusing on differences between workers in the same job. ${ }^{50}$

\subsection{Robustness Tests}

As mentioned in Section 2, questions about the workers are answered by the person responsible for hiring in an establishment. Although most establishments in the data are small (the median establishment employs 23 workers), one might worry that respondents in the larger establishments are less likely

\footnotetext{
50 This result holds even when I exclude observations in which the two workers had the same referral type.
} 
to be the workers' immediate supervisors and might be less able to accurately evaluate the workers' productivity. Since establishment size does vary by referral type, columns 2 and 3 of Table 4 present results that restrict the sample to establishments with not more than 100 and not more than 50 workers, respectively. (Column 1 presents the main results from Table 3a for comparison.) The coefficients for referrals from employees and from friends and family of the employer are not noticeably affected by these restrictions, suggesting that these results are not driven by differences in firm size. The coefficient on a referral from another firm or a labor union does fall when establishments of more than 50 workers are excluded; however, this restriction may not be appropriate for these referrals because they are associated with larger firms. ${ }^{51}$

Another concern, which is mentioned in Section 3, is that human capital accumulation on the job might vary by referral type. The preferred specification addresses this by including controls for tenure and its interactions with referral type, but direct information on training is excluded because of its likely endogeneity. Column 4 of Table 4 adds differences in hours of both formal and informal training, as well as a dummy variable for missing training information. ${ }^{52}$ None of the coefficients of interest appear sensitive to the addition of training variables, which they should be if differences in human capital accumulation were affecting the results. ${ }^{53}$

\footnotetext{
51 Of the 49 workers referred by another firm or labor union, 16 are establishments with more than 50 workers. On the other hand, only seven of 48 workers referred by the employer's friends or family members are lost when this restriction is imposed.

52 The coefficients on training (not shown) are small and negative. Only the coefficient on hours of informal training is statistically significant at -0.004 (0.002).

53 Altonji and Pierret (2001) perform a similar robustness check in their work on employer learning and statistical discrimination.
} 
Finally, Section 3.3 discusses problems that might arise due to the productivity evaluations being ordinal rankings. Coefficients in Table 3 could be biased toward zero if there is some job-specific scaling of the productivity evaluations that is not removed by the use of differences. Controlling for a variable that is correlated with the level of productivity that the employer expects in the job should reduce any such bias. Column 5 of Table 4 presents results from a regression that controls for the hourly wage of the "typical" worker in the job after two years of tenure. ${ }^{54}$ Once again, the coefficients of interest are very close to those from Table 3, suggesting that the main results are robust to effects of job-specific scaling of the productivity measure that aren't removed by differencing.

\subsection{Performance Regressions}

If referrals allow employers to more accurately evaluate job applicants, workers hired through these referrals should have higher productivity than workers hired without one. Although there are other reasons referrals and worker productivity might be related, I examine this relationship in Table 5, which presents results from regressions of the difference in current productivity between workers in the same job. ${ }^{55}$ Column II allows the effect of a referral on productivity to vary

\footnotetext{
54 The "typical" wage and a corresponding missing value dummy variable enter as the only non-differenced variables in this regression. The hourly wage variable has a coefficient of 0.077 (0.022). Controlling for a polynomial in the typical wage, or the typical wage interacted with productivity differences, produces similar results.

55 I use differences in productivity because productivity evaluations are relative to the expectations of the job. Due to the size of the sample, I do not exclude observations from these regressions that were excluded from previous results for missing wage values.
} 
with tenure, while column I does not. ${ }^{56}$

The results in Table 5 suggest that workers hired through referrals from employees and from other firms or labor unions have higher productivity than similar workers hired with no referrals. ${ }^{57}$ In column I, the coefficients on referrals from employees and from other firms or labor unions are large and statistically significant at $8.16(3.62)$ and $14.84(6.94)$, respectively. In contrast, there is no evidence that referrals from the employer's friends or relatives are associated with higher productivity, further supporting the idea that these referrals might involve favoritism. ${ }^{58}$

The results in column II suggest that the positive effect of an employee referral persists after hiring, as in Castilla (2005), while the effect of a referral from another firm or labor union fades with time on the job. The coefficient on employee referrals changes very little in column II, and there is no evidence that workers referred by an employee accumulate human capital at a different rate from non-referred workers once the job starts. ${ }^{59}$ On the other hand, the coefficient on a referral from another firm or a labor union rises to 22.19 (8.04), and the coefficient on the interaction of tenure with referrals from employers or unions is $-0.79(0.32)$.

\footnotetext{
56 The regressions presented in each column control for the same variables used in regressions on current wage differences.

57 These results confirm results in Holzer (1987) that do not look at differences between workers in the same job.

58 This is particularly interesting given that these are subjective performance evaluations. Employers could inflate evaluations to justify the premiums paid to workers they hire through their own friends and family, but Table 5 doesn't suggest that they do.

59 This provides further evidence suggesting that faster learning on the job is not likely to confound results for this group.
} 


\section{Discussion}

The evidence presented in this paper suggests that referrals from current employees provide employers with more information about job applicants than they would have otherwise. Evaluations of a worker's productivity have a larger (more positive) effect on wages at the time of hiring for these workers than for workers who where hired without a referral, and employer learning has less of an effect on their wages. The results are similar for referrals from other firms or labor unions; however, the difference in employer learning is not statistically significant for this relatively rare referral type.

In contrast, the results appear to suggest that employers obtain less information at the time of hiring about workers who were referred by friends and relatives of the employer than they would collect without a referral. This result is consistent with favoritism allowing these workers to be hired with less scrutiny than other applicants, or with information simply being ignored when their wages are set. Providing further evidence of favoritism, I find that referrals from friends or family of the employer are unique in that they don't on average result in hiring more productive workers, but they are associated with a wage premium that declines with tenure on the job.

The results of this paper are consistent with the intuition expressed by Rees and Schultz (1970) and elsewhere. An employee who refers a friend or relative will at least be able to comment on character traits like honesty and reliable. ${ }^{60}$

\footnotetext{
${ }^{60}$ Holzer (1906) suggests, as have others, that behavioral issues, such as absenteeism, are relatively more important in less-skilled work. The data in this paper are from a survey that over-samples low-wage jobs.
} 
Previous employers and labor unions could transmit useful information through a referrals because they have observed the worker's past work or training. Finally, if any type of referral is to involve favoritism, it comes as no surprise that evidence of favoritism is found for referrals from the employer's own friends and family members. ${ }^{61}$

Finding that referrals from employees, other firms and labor unions provide employers with more information than other hiring channels is consistent with earlier results in the literature. For example, Holzer (1988) and Blau and Robins (1990) find that referrals from a worker's friends and family are more effective than other search methods when it comes to producing offers and acceptances. The statistical discrimination model of Cornell and Welch (1996) suggests that employers having more precise information about applicants with these types of referrals would explain the higher rate of offers these referrals generate. The variance of expected productivity conditional on a signal is higher the more precise that signal is, which makes it more likely that the worker with highest conditional expectation in a pool of applicants is from the group with the most precise signal. Even if employers eventually learn everything about any worker they hire, workers with informative referrals will have an advantage in the hiring process. Similarly, employers are likely to hire workers who are more productive on average when their information about the ability of applicants is more precise, which is consistent with the results of Holzer (1987) and Castilla (2005) (and is confirmed by this paper).

\footnotetext{
61 Simon and Warner (1992) correctly not that favoritism is not consistent with competitive labor markets; however, favoritism could be persistent in less competitive markets, just as discrimination could be.
} 
Of course, workers hired through informative referrals might also be more productive (receive more job offers, etc.) because they are drawn from a pool of applicants that are more capable on average, because of peer pressure, or for some other reason. The work of FCM, Castilla (2005) and others in the sociology literature has emphasized the fact that no one effect of social networks on the workplace happens in isolation. This paper has focused on only one part of a larger picture. Evidence that firms learn more from referrals than other recruiting channels does not imply that referrals do not have many other effects, even if those other effects do not explain the particular testable implications this paper has focused on.

One avenue for future research would be the application of the tests developed in this paper to data from firms' personnel records. This would allow researchers to consider whether a specific firm was learning more from some recruiting methods than from others while also looking more broadly at the role of referrals in a firm, as recommended by FCM. For example, the data used in Petersen, et al (2000) or Castilla (2005) could be used to conduct tests similar to those in this paper while also providing detail on those firms that the cross-sectional data used in this paper does not have. 


\section{References}

[1] Aigner, Dennis J., and Glen G. Cain. (1977) "Statistical Theories of Discrimination in Labor Markets," Industrial and Labor Relations Review, vol 30, pp175-87.

[2] Altonji, Joseph, and Charles Pierret. (2001) "Employer Learning and Statistical Discrimination." The Quarterly Journal of Economics. 116.1: 313350.

[3] Bishop, John. (1987) "The Recognition and Reward of Employee Performance," Journal of Labor Economics, vol 5(4), pp. S36-S56.

[4] Blau, David M., and Philip K. Robins. (1990) "Job Search Outcomes for Employed and Unemployed," Journal of Political Economy, vol 98(3).

[5] Castilla, Emilio J. (2005) "Social Networks and Employee Performance in a Call Center", American Journal of Sociology, vol. 110(5), pp. 1243-83.

[6] Calvó-Armengol, Antoni, and Matthew O. Jackson (2004) "The Effects of Social Networks on Employment and Inequality", The American Economic Review, vol. 94(3), pp. 426-454.

[7] Cornell, Bradford, and Ivo Welch. (1996) "Culture, Information, and Screening Discrimination," Journal of Political Economy, vol. 104(3).

[8] Devaro, Jed. (2005) "Employer Recruitment Strategies and the Labor Market Outcomes of New Hires," Economic Inquiry, vol 43(2).

[9] Fernandez, Robert M., and Nancy Weinberg. (1997) "Sifting and Sorting: Personal Contacts and Hiring in a Retail Bank", American Sociological Review, vol 62, pp. 883-902.

[10] Fernandez, Roberto M, Emilio J. Castilla, and Paul Moore. (2000) "Social Capital at Work: Networks and Employment at a Phone Center." American Journal of Sociology. 105.5

[11] Frazis, Harley and Mark Loewenstein. (2007) "Wage Compression and the Division of Returns to Productivity Growth: Evidence from EOPP", Bureau of Labor Statistics.

[12] Gibbons, Robert, and Michael Waldman. "Careers in Organizations: Theory and Evidence," Chapter 36, Handbook of Labor Economics, Vol. 3, 1999.

[13] Holzer, Harry J. (1987) "Hiring Procedures in the Firm: Their Economic Determinants and Outcomes," in R. Block, et. al. (eds.), Human Resources and Firm Performance, Industrial Relations Research Association.

[14] _ _ _ _ (1988) "Search Method Use by Unemployed Youth," Journal of Labor Economics, vol. 6(1). 
[15] Educated Workers. Russell Sage Foundation, New York.

[16] Jovanovic, Boyan. (1979) "Job Matching and the Theory of Turnover," Journal of Political Economy, vol. 92, pp108-22.

[17] Kugler, Adriana D. (2003) "Employee Referrals and Efficiency Wages," Labour Economics, vol. 10(5), pp. 531-56.

[18] Loury, Linda Datcher. (2006) "Some Contacts Are More Equal than Others: Informal Networks, Job Tenure, and Wages", Journal of Labor Economics, vol 24(2), pp. 299-318.

[19] Marmaros, David, and Bruce Sacerdote. (2002) "Peer and Social Networks in Job Search", European Economic Review, vol. 46, pp. 870-879.

[20] Mayer, Adalbert. (2010) "Empirical Evidence on the Role of Social Networks in Job Search", mimeo, Texas A\&M University.

[21] Montgomery, James D. (1991) "Social Networks and Labor-Market Outcomes: Toward an Economic Analysis", The American Economic Review, vol. 81(5), pp. 1408-18.

[22] Mortensen, Dale T. (1988) "Wages, Separations and Job Tenure: On-theJob Specific Training or Matching?", Journal of Labor Economics, vol 6(4), pp. $445-71$.

[23] Mouw, Ted. (2003) "Social Capital and Finding a Job: Do Contacts Matter?" American Journal of Sociology, vol. 68, 868-98.

[24] Petersen, Trond, Ishak Saporta, and Marc-David L. Seidel. (2000) "Offering a Job: Meritocracy and Social Networks." American Journal of Sociology. 106.3: $763-816$.

[25] Pinkston, Joshua C. (2003) "Screening Discrimination and the Determinants of Wages," Labour Economics, vol. 10, pp 643-58.

[26] _ _ (2009) "A Model of Asymmetric Employer Learning with Testable Implications," Review of Economic Studies, vol. 76(1), pp. 367394.

[27] Rees, Albert, and George P. Schultz. (1970) Workers and Wages in an Urban Labor Market. The University of Chicago Press, Chicago.

[28] Reynolds, Lloyd. (1951) The Structure of Labor Markets. Harper \& Row, New York.

[29] Saloner, Garth. (1985) "Old Boy Networks as Screening Mechanisms", Journal of Labor Economics, vol. 3(3), pp. 255-67. 
[30] Scoones, David, and Dan Bernhardt. (1998) "Promotion, Turnover, and Discretionary Human Capital Acquisition," Journal of Labor Economics, 16, pp. 122-41.

[31] Shinnar, Rachel S., Cheri A. Young and Marta Meana. (2004) "The Motivations for and Outcomes of Employee Referrals", Journal of Business and Psychology, vol 19(2), pp. 271-83.

[32] Simon, Curtis J., and John T. Warner. (1992) "Matchmaker, Matchmaker: The Effect of Old Boy Networks on Job Match Quality, Earnings, and Tenure," Journal of Labor Economics, vol. 10(3).

[33] Waldman, Michael. (1984) "Job Assignments, Signaling and Efficiency," Rand Journal of Economics, 15, pp. 255-67.

[34] Yakubovich, Valery, and Daniela Lup. (2006) "Stages of the Recruitment Process and the Referrer's Performance Effect," Organization Science, vol. 17(6), 710-23. 


\section{Table 1. Summary Statistics}

\begin{tabular}{|c|c|c|c|}
\hline & Mean & Std Dev. & Number of Obs. \\
\hline Initial Wage & 5.155 & 2.332 & 884 \\
\hline Current Wage & 5.482 & 2.464 & 894 \\
\hline Initial Productivity & 52.471 & 25.908 & 894 \\
\hline Current Productivity & 76.277 & 19.929 & 894 \\
\hline High School & 0.611 & 0.488 & 859 \\
\hline Some College & 0.197 & 0.398 & 859 \\
\hline College & 0.050 & 0.218 & 859 \\
\hline Age & 25.892 & 8.987 & 871 \\
\hline Female & 0.457 & 0.498 & 894 \\
\hline Relevant Experience & 42.813 & 57.655 & 465 \\
\hline Tenure & 10.766 & 8.240 & 894 \\
\hline Establishment Size & 133.436 & 966.657 & 894 \\
\hline Prof., Man., Tech. & 0.078 & 0.269 & 894 \\
\hline Service & 0.172 & 0.378 & 894 \\
\hline Clerical and Sales & 0.400 & 0.490 & 894 \\
\hline Machine Work & 0.136 & 0.343 & 894 \\
\hline Bench Work & 0.025 & 0.155 & 894 \\
\hline Structural Work & 0.076 & 0.265 & 894 \\
\hline Referral Source: & & & \\
\hline$\overline{\text { Employee }}$ & 0.256 & 0.437 & 894 \\
\hline Employer's Friend & 0.054 & 0.226 & 894 \\
\hline Other Firm/Union & 0.055 & 0.228 & 894 \\
\hline Other Source & 0.183 & 0.387 & 894 \\
\hline No Referral & 0.452 & 0.498 & 894 \\
\hline
\end{tabular}

Notes: The sample is limited to observations used in current wage regressions.

Relevant Experience and Tenure are measured in months. 
Table 2. Summary Statistics by Referral Source

\begin{tabular}{|c|c|c|c|c|c|}
\hline & Employee & $\begin{array}{c}\text { Employer's } \\
\text { Friend/Family }\end{array}$ & $\begin{array}{c}\text { Other Firm } \\
\text { or Labor Union }\end{array}$ & Other Source & No Referral \\
\hline Initial Wage & $\begin{array}{c}5.270 \\
(0.159)\end{array}$ & $\begin{array}{c}5.643 \\
(0.387)\end{array}$ & $\begin{array}{c}6.402 \\
(0.510)\end{array}$ & $\begin{array}{c}4.745 \\
(0.169)\end{array}$ & $\begin{array}{c}5.050 \\
(0.104)\end{array}$ \\
\hline Current Wage & $\begin{array}{c}5.556 \\
(0.162)\end{array}$ & $\begin{array}{c}6.275 \\
(0.488)\end{array}$ & $\begin{array}{l}7.177 \\
(0.554)\end{array}$ & $\begin{array}{c}4.938 \\
(0.165)\end{array}$ & $\begin{array}{c}5.362 \\
(0.106)\end{array}$ \\
\hline Initial Productivity & $\begin{array}{l}52.293 \\
(1.740)\end{array}$ & $\begin{array}{l}58.750 \\
(3.229)\end{array}$ & $\begin{array}{l}62.000 \\
(3.392)\end{array}$ & $\begin{array}{l}45.994 \\
(2.046)\end{array}$ & $\begin{array}{l}53.300 \\
(1.277)\end{array}$ \\
\hline Current Productivity & $\begin{array}{l}77.157 \\
(1.243)\end{array}$ & $\begin{array}{l}79.646 \\
(2.181)\end{array}$ & $\begin{array}{l}82.265 \\
(2.440)\end{array}$ & $\begin{array}{l}73.799 \\
(1.725)\end{array}$ & $\begin{array}{l}75.658 \\
(1.010)\end{array}$ \\
\hline High School & $\begin{array}{c}0.636 \\
(0.033)\end{array}$ & $\begin{array}{c}0.578 \\
(0.074)\end{array}$ & $\begin{array}{c}0.667 \\
(0.069)\end{array}$ & $\begin{array}{c}0.535 \\
(0.040)\end{array}$ & $\begin{array}{c}0.624 \\
(0.025)\end{array}$ \\
\hline Some College & $\begin{array}{c}0.195 \\
(0.027)\end{array}$ & $\begin{array}{c}0.156 \\
(0.055)\end{array}$ & $\begin{array}{c}0.167 \\
(0.054)\end{array}$ & $\begin{array}{c}0.206 \\
(0.033)\end{array}$ & $\begin{array}{c}0.202 \\
(0.020)\end{array}$ \\
\hline College & $\begin{array}{c}0.041 \\
(0.013)\end{array}$ & $\begin{array}{c}0.089 \\
(0.043)\end{array}$ & $\begin{array}{c}0.042 \\
(0.029)\end{array}$ & $\begin{array}{c}0.065 \\
(0.020)\end{array}$ & $\begin{array}{c}0.046 \\
(0.011)\end{array}$ \\
\hline Age & $\begin{array}{l}25.740 \\
(0.639)\end{array}$ & $\begin{array}{l}24.717 \\
(1.057)\end{array}$ & $\begin{array}{l}28.146 \\
(1.457)\end{array}$ & $\begin{array}{l}24.258 \\
(0.603)\end{array}$ & $\begin{array}{l}26.522 \\
(0.461)\end{array}$ \\
\hline Female & $\begin{array}{c}0.450 \\
(0.033)\end{array}$ & $\begin{array}{c}0.417 \\
(0.072)\end{array}$ & $\begin{array}{c}0.429 \\
(0.071)\end{array}$ & $\begin{array}{c}0.488 \\
(0.039)\end{array}$ & $\begin{array}{c}0.458 \\
(0.025)\end{array}$ \\
\hline Relevant Experience & $\begin{array}{l}41.843 \\
(4.502)\end{array}$ & $\begin{array}{l}35.333 \\
(8.195)\end{array}$ & $\begin{array}{l}54.031 \\
(9.565)\end{array}$ & $\begin{array}{l}30.232 \\
(4.388)\end{array}$ & $\begin{array}{l}47.347 \\
(4.685)\end{array}$ \\
\hline Tenure & $\begin{array}{l}12.409 \\
(0.597)\end{array}$ & $\begin{array}{l}11.804 \\
(1.320)\end{array}$ & $\begin{array}{l}10.429 \\
(1.114)\end{array}$ & $\begin{array}{l}11.220 \\
(0.643)\end{array}$ & $\begin{array}{l}9.903 \\
(0.367)\end{array}$ \\
\hline Establishment Size & $\begin{array}{c}63.585 \\
(17.319)\end{array}$ & $\begin{array}{l}30.792 \\
(6.143)\end{array}$ & $\begin{array}{c}80.327 \\
(17.991)\end{array}$ & $\begin{array}{l}111.817 \\
(26.342)\end{array}$ & $\begin{array}{l}200.443 \\
(69.910)\end{array}$ \\
\hline Prof., Man., Tech. & $\begin{array}{c}0.122 \\
(0.022)\end{array}$ & $\begin{array}{c}0.125 \\
(0.048)\end{array}$ & $\begin{array}{l}0.082 \\
(0.040)\end{array}$ & $\begin{array}{c}0.067 \\
(0.020)\end{array}$ & $\begin{array}{c}0.052 \\
(0.011)\end{array}$ \\
\hline Service & $\begin{array}{c}0.170 \\
(0.025)\end{array}$ & $\begin{array}{c}0.229 \\
(0.061)\end{array}$ & $\begin{array}{c}0.061 \\
(0.035)\end{array}$ & $\begin{array}{c}0.171 \\
(0.029)\end{array}$ & $\begin{array}{c}0.181 \\
(0.019)\end{array}$ \\
\hline Clerical and Sales & $\begin{array}{c}0.349 \\
(0.032)\end{array}$ & $\begin{array}{c}0.354 \\
(0.070)\end{array}$ & $\begin{array}{c}0.429 \\
(0.071)\end{array}$ & $\begin{array}{c}0.445 \\
(0.039)\end{array}$ & $\begin{array}{c}0.413 \\
(0.025)\end{array}$ \\
\hline Machine Work & $\begin{array}{c}0.118 \\
(0.021)\end{array}$ & $\begin{array}{c}0.188 \\
(0.057)\end{array}$ & $\begin{array}{c}0.102 \\
(0.044)\end{array}$ & $\begin{array}{c}0.110 \\
(0.024)\end{array}$ & $\begin{array}{c}0.156 \\
(0.018)\end{array}$ \\
\hline Bench Work & $\begin{array}{c}0.004 \\
(0.004)\end{array}$ & $\begin{array}{c}0.021 \\
(0.021)\end{array}$ & $\begin{array}{c}0.041 \\
(0.029)\end{array}$ & $\begin{array}{c}0.030 \\
(0.013)\end{array}$ & $\begin{array}{c}0.032 \\
(0.009)\end{array}$ \\
\hline Structural Work & $\begin{array}{c}0.092 \\
(0.019)\end{array}$ & $\begin{array}{c}0.063 \\
(0.035)\end{array}$ & $\begin{array}{c}0.061 \\
(0.035)\end{array}$ & $\begin{array}{c}0.061 \\
(0.019)\end{array}$ & $\begin{array}{c}0.077 \\
(0.013)\end{array}$ \\
\hline Current Wage Obs. & 229 & 48 & 49 & 164 & 404 \\
\hline
\end{tabular}

Notes: Standard errors are in parentheses. The sample is limited to observations used in current wage regressions.

Relevant Experience and Tenure are measured in months. 


\section{Table 3a. Current Wage Regressions: Referral Types,}

the Initial Effects of Productivity, and Employer Learning

\begin{tabular}{|c|c|c|}
\hline & $\begin{array}{c}\text { I } \\
\text { Pooled Regressions }\end{array}$ & $\begin{array}{c}\text { II } \\
\text { Wage Differences }\end{array}$ \\
\hline Employee Referral & $\begin{array}{l}-0.3492 \\
(1.5028)\end{array}$ & $\begin{array}{l}-1.6646 \\
(0.7253)\end{array}$ \\
\hline Employer's Frnd/Fam & $\begin{array}{l}-2.9334 \\
(1.3556)\end{array}$ & $\begin{array}{l}2.6585 \\
(0.9655)\end{array}$ \\
\hline Firm/Union Referral & $\begin{array}{l}-8.7880 \\
(3.7641)\end{array}$ & $\begin{array}{l}-1.5969 \\
(1.3911)\end{array}$ \\
\hline Other Referral & $\begin{array}{l}-2.3944 \\
(0.9020)\end{array}$ & $\begin{array}{l}-0.1927 \\
(0.8322)\end{array}$ \\
\hline Productivity & $\begin{array}{l}-0.0056 \\
(0.0085)\end{array}$ & $\begin{array}{c}0.0039 \\
(0.0052)\end{array}$ \\
\hline Productivity $\mathrm{x}$ Tenure & $\begin{array}{c}0.0011 \\
(0.0006)\end{array}$ & $\begin{array}{c}0.0006 \\
(0.0006)\end{array}$ \\
\hline Prod. x Employee Ref. & $\begin{array}{c}0.0133 \\
(0.0177)\end{array}$ & $\begin{array}{c}0.0196 \\
(0.0101)\end{array}$ \\
\hline Prod. x Employer Ref. & $\begin{array}{c}0.0560 \\
(0.0191)\end{array}$ & $\begin{array}{l}-0.0278 \\
(0.0120)\end{array}$ \\
\hline Prod. x Firm/Union Ref. & $\begin{array}{c}0.1012 \\
(0.0435)\end{array}$ & $\begin{array}{c}0.0266 \\
(0.0155)\end{array}$ \\
\hline Prod. x Other Ref. & $\begin{array}{c}0.0338 \\
(0.0101)\end{array}$ & $\begin{array}{c}0.0021 \\
(0.0113)\end{array}$ \\
\hline $\begin{array}{l}\text { Prod x Tenure } \\
\text { x Employee Ref. }\end{array}$ & $\begin{array}{l}-0.0018 \\
(0.0014)\end{array}$ & $\begin{array}{l}-0.0015 \\
(0.0007)\end{array}$ \\
\hline $\begin{array}{l}\text { Prod x Tenure } \\
\text { x Employer Ref. }\end{array}$ & $\begin{array}{l}-0.0001 \\
(0.0020)\end{array}$ & $\begin{array}{c}0.0021 \\
(0.0009)\end{array}$ \\
\hline $\begin{array}{l}\text { Prod } x \text { Tenure } \\
\text { x Firm/Union Ref. }\end{array}$ & $\begin{array}{l}-0.0129 \\
(0.0046)\end{array}$ & $\begin{array}{l}-0.0016 \\
(0.0022)\end{array}$ \\
\hline $\begin{array}{c}\text { Prod } x \text { Tenure } \\
\text { x Other Ref. }\end{array}$ & $\begin{array}{l}-0.0017 \\
(0.0008)\end{array}$ & $\begin{array}{l}-0.0003 \\
(0.0009)\end{array}$ \\
\hline Observations & 894 & 447 worker pairs \\
\hline
\end{tabular}

Notes: Standard errors (in parentheses) are Huber/White allowing for dependence within survey site. The regression in column I includes a quartic polynomial in age; gender; dummy variables for education; relevant experience; tenure; missingvalue dummies for age, education, and experience; and all appropriate interactions of tenure. The job characteristics in column I are dummy variables for survey site, occupation and industry; the number of employees in the establishment; the percent unionized and its missing-value dummy. The regression in column II controls for differences in individual characteristics used in column I. 


\section{Table 3b. Current Wage Regressions: Differences in Effects}

of a One Standard Deviation Increase in Productivity on Wages.

\begin{tabular}{c|c|c|c|c}
\hline & Employee & $\begin{array}{c}\text { Employer's Friend } \\
\text { or Family }\end{array}$ & $\begin{array}{c}\text { Other Firm or } \\
\text { Labor Union }\end{array}$ & $\begin{array}{c}\text { Other Referral } \\
\text { Sources }\end{array}$ \\
\hline $\begin{array}{c}\text { Tenure = 0 } \\
\text { months }\end{array}$ & 0.3912 & -0.5561 & 0.5314 & 0.0413 \\
$\begin{array}{c}\text { Tenure = 6 } \\
\text { months }\end{array}$ & $(0.2030)$ & $(0.2404)$ & $(0.3103)$ & $(0.2268)$ \\
$\begin{array}{c}\text { Tenure = 12 } \\
\text { months }\end{array}$ & 0.2064 & -0.3092 & 0.3416 & 0.0096 \\
$\begin{array}{c}\text { Tenure = 18 } \\
\text { months }\end{array}$ & $(0.1463)$ & $(0.1710)$ & $(0.0929)$ & $(0.1558)$ \\
\hline Nons) & $-0.1279)$ & $(0.1470)$ & 0.1518 & -0.0221 \\
& $(0.1614)$ & 0.1845 & $(0.2520)$ & $(0.1342)$ \\
\hline
\end{tabular}

Notes: Effects are calculated using the regression presented in column II of Table 3a. Effects are differences from those of workers hired without a referral. A one standard deviation increase in productivity is rounded to 20 .

\section{Table 3c. Current Wage Regressions: Effects of Referral Type} on Wages at Average Performance.

\begin{tabular}{c|c|c|c|c}
\hline & Employee & $\begin{array}{c}\text { Employer's Friend } \\
\text { or Family }\end{array}$ & $\begin{array}{c}\text { Other Firm or } \\
\text { Labor Union }\end{array}$ & $\begin{array}{c}\text { Other Referral } \\
\text { Sources }\end{array}$ \\
\hline $\begin{array}{c}\text { Tenure = 0 } \\
\text { months }\end{array}$ & -0.1586 & 0.5177 & 0.4489 & -0.0335 \\
Tenure = 6 & $(0.1607)$ & $(0.1810)$ & $(0.3177)$ & $(0.2897)$ \\
months & -0.1000 & 0.3250 & 0.4343 & -0.0708 \\
Tenure = 12 & $(0.1048)$ & $(0.1250)$ & $(0.2056)$ & $(0.2026)$ \\
months & -0.0414 & 0.1323 & 0.4197 & -0.1081 \\
Tenure = 18 & $(0.0895)$ & $(0.1035)$ & $(0.2297)$ & $(0.1483)$ \\
months & 0.0172 & -0.0604 & 0.4051 & -0.1454 \\
\hline
\end{tabular}

Notes: Effects are calculated using the regression presented in column II of Table 3a. All effects are relative to those for workers hired without a referral. Average performance is rounded up to 77 . 
Table 4. Robustness Checks: Effects on Current Wage Differences

\begin{tabular}{|c|c|c|c|c|c|}
\hline & $\begin{array}{c}\text { (1) } \\
\text { Main Results }\end{array}$ & $\begin{array}{c}(2) \\
\text { Establishment } \\
\text { Size }<=100\end{array}$ & $\begin{array}{c}(3) \\
\text { Establishment } \\
\text { Size }<=50\end{array}$ & $\begin{array}{c}(4) \\
\text { Training } \\
\text { Variables }\end{array}$ & $\begin{array}{c}\text { (5) } \\
\text { Typical Wage }\end{array}$ \\
\hline Productivity & $\begin{array}{c}0.0039 \\
(0.0052)\end{array}$ & $\begin{array}{c}0.0041 \\
(0.0054)\end{array}$ & $\begin{array}{c}0.0044 \\
(0.0053)\end{array}$ & $\begin{array}{c}0.0019 \\
(0.0053)\end{array}$ & $\begin{array}{c}0.0038 \\
(0.0045)\end{array}$ \\
\hline Productivity $\mathrm{x}$ Tenure & $\begin{array}{c}0.0006 \\
(0.0006)\end{array}$ & $\begin{array}{c}0.0005 \\
(0.0007)\end{array}$ & $\begin{array}{c}0.0005 \\
(0.0007)\end{array}$ & $\begin{array}{c}0.0006 \\
(0.0006)\end{array}$ & $\begin{array}{c}0.0005 \\
(0.0005)\end{array}$ \\
\hline Prod. x Employee Ref. & $\begin{array}{c}0.0196 \\
(0.0101)\end{array}$ & $\begin{array}{c}0.0208 \\
(0.0108)\end{array}$ & $\begin{array}{c}0.0204 \\
(0.0108)\end{array}$ & $\begin{array}{c}0.0217 \\
(0.0103)\end{array}$ & $\begin{array}{c}0.0198 \\
(0.0088)\end{array}$ \\
\hline Prod. x Employer Ref. & $\begin{array}{l}-0.0278 \\
(0.0120)\end{array}$ & $\begin{array}{l}-0.0282 \\
(0.0125)\end{array}$ & $\begin{array}{l}-0.0314 \\
(0.0127)\end{array}$ & $\begin{array}{l}-0.0262 \\
(0.0119)\end{array}$ & $\begin{array}{l}-0.0290 \\
(0.0126)\end{array}$ \\
\hline Prod. x Firm/Union Ref. & $\begin{array}{c}0.0266 \\
(0.0155)\end{array}$ & $\begin{array}{c}0.0279 \\
(0.0162)\end{array}$ & $\begin{array}{c}0.0128 \\
(0.0129)\end{array}$ & $\begin{array}{c}0.0272 \\
(0.0151)\end{array}$ & $\begin{array}{c}0.0282 \\
(0.0171)\end{array}$ \\
\hline Prod. x Other Ref. & $\begin{array}{c}0.0021 \\
(0.0113)\end{array}$ & $\begin{array}{c}0.0026 \\
(0.0120)\end{array}$ & $\begin{array}{c}0.0036 \\
(0.0133)\end{array}$ & $\begin{array}{c}0.0010 \\
(0.0115)\end{array}$ & $\begin{array}{c}0.0019 \\
(0.0109)\end{array}$ \\
\hline $\begin{array}{l}\text { Prod x Tenure } \\
\text { x Employee Ref. }\end{array}$ & $\begin{array}{l}-0.0015 \\
(0.0007)\end{array}$ & $\begin{array}{l}-0.0016 \\
(0.0008)\end{array}$ & $\begin{array}{l}-0.0015 \\
(0.0007)\end{array}$ & $\begin{array}{l}-0.0017 \\
(0.0007)\end{array}$ & $\begin{array}{l}-0.0015 \\
(0.0006)\end{array}$ \\
\hline $\begin{array}{l}\text { Prod x Tenure } \\
\text { x Employer Ref. }\end{array}$ & $\begin{array}{c}0.0021 \\
(0.0009)\end{array}$ & $\begin{array}{c}0.0022 \\
(0.0009)\end{array}$ & $\begin{array}{c}0.0022 \\
(0.0009)\end{array}$ & $\begin{array}{c}0.0020 \\
(0.0008)\end{array}$ & $\begin{array}{c}0.0025 \\
(0.0007)\end{array}$ \\
\hline $\begin{array}{l}\text { Prod } x \text { Tenure } \\
\text { x Firm/Union Ref. }\end{array}$ & $\begin{array}{l}-0.0016 \\
(0.0022)\end{array}$ & $\begin{array}{l}-0.0018 \\
(0.0023)\end{array}$ & $\begin{array}{c}0.0012 \\
(0.0016)\end{array}$ & $\begin{array}{l}-0.0015 \\
(0.0022)\end{array}$ & $\begin{array}{l}-0.0016 \\
(0.0024)\end{array}$ \\
\hline $\begin{array}{c}\text { Prod } x \text { Tenure } \\
\text { x Other Ref. }\end{array}$ & $\begin{array}{l}-0.0003 \\
(0.0009)\end{array}$ & $\begin{array}{l}-0.0003 \\
(0.0009)\end{array}$ & $\begin{array}{l}-0.0003 \\
(0.0009)\end{array}$ & $\begin{array}{l}-0.0001 \\
(0.0008)\end{array}$ & $\begin{array}{l}-0.0002 \\
(0.0007)\end{array}$ \\
\hline Observations & 447 & 367 & 323 & 447 & 447 \\
\hline
\end{tabular}

Notes: The regression in column (1) is the same as column II in Table 3a. Columns (2) and (3) restrict the sample to jobs in establishments with 100 or fewer workers and 50 or fewer workers, respectively. Column (4) uses the full sample, but adds differences in formal and informal training, as well as a dummy variable for missing training information. Column (5) controls for the hourly wage of the "typical" worker after two years on the job, and a corresponding missing value dummy variable. 
Table 5. Effects of Referrals on Current Productivity

\begin{tabular}{l|c|c}
\hline & $\mathrm{I}$ & $\mathrm{II}$ \\
\hline Employee Referral & 8.160 & 9.922 \\
& $(3.620)$ & $(5.906)$ \\
Employer's Frnd/Fam & 4.770 & 1.786 \\
& $(5.111)$ & $(8.090)$ \\
Firm/Union Referral & 14.842 & 22.192 \\
& $(6.943)$ & $(8.041)$ \\
Other Referral & 0.189 & 4.524 \\
& $(5.506)$ & $(6.445)$ \\
\hline Tenure & 0.273 & 0.475 \\
& $(0.132)$ & $(0.207)$ \\
\hline Employee Referral & $\ldots .$. & -0.195 \\
X Tenure & & $(0.423)$ \\
Employer's Frnd/Fam & $\ldots .$. & 0.168 \\
X Tenure & $\ldots .$. & $(0.446)$ \\
Firm/Union Referral & $\ldots$. & -0.790 \\
X Tenure & & $(0.316)$ \\
Other Referral & & -0.380 \\
x Tenure & 462 worker pairs & $(0.473)$ \\
\hline Observations & 462 worker pairs \\
\hline
\end{tabular}

Notes: Standard errors (in parentheses) are Huber/White allowing for dependence within survey site. Regressions also include differences in a quartic age polynomial; relevant experience; gender; dummy variables for education; missing-value dummies for experience, schooling, and age. 